\title{
Influence of fiber reinforcement towards the physical characteristics of low density polyethylene laminated composites
}

\author{
S. Ravichandran ${ }^{1)}$ *), A. Daniel Raj ${ }^{2)}$, P. Balaji Visvanath ${ }^{2)}$, Faruq Mohammad ${ }^{3)}$, \\ Hamad A. Al-Lohedan ${ }^{3)}$, Suresh Sagadevan ${ }^{4), *)}$
}

DOI: dx.doi.org/10.14314/polimery.2020.6.4

\begin{abstract}
In recent years, the increased interest in the design and fabrication of lightweight polymer composites with various combinations and stoichiometry is due to their enhancement of electrical, mechanical, thermal, and biological properties compared to the properties of conventional materials. With that view, the present study deals with the effects of low density polyethylene composites (LDPE) reinforced with epoxy resin, glass fiber, carbon fiber, and Kevlar towards the mechanical, thermal, and water absorption properties. The mechanical studies showed that the LDPE composite reinforced carbon fiber has the best tensile properties compared to other composites and this can be mostly due to the proper bonding and associated interaction between the polymeric matrix and the bidirectional layer of the fibers. Also, the carbon fiber reinforced composite has superior properties of impart energy compared to the other composites and the non-reinforced ones and this is attributed to the crystalline nature of carbon fiber. Further studies of the thermal properties indicated that the retention of thermal stability for all the fiber-reinforced polymer composites, while the water absorption revealed a considerable increase in the weight of Kevlar fiber-reinforced composite. From the overall analysis, the enhanced properties of LDPE matrix reinforced fibers are linked to the morphological changes that occurred and are directly affected by the nature of the fiber.
\end{abstract}

Keywords: low density polyethylene composites, mechanical properties, thermal studies, water absorption study, epoxy resin, Kevlar fiber, glass fiber, carbon fiber.

\section{Wpływ rodzaju włókien na właściwości fizyczne laminatowych kompozytów polietylenu małej gęstości}

Streszczenie: Zwiększone $w$ ostatnich latach zainteresowanie projektowaniem i wytwarzaniem lekkich kompozytów polimerowych wynika z ich lepszych właściwości elektrycznych, mechanicznych, termicznych i biologicznych w porównaniu z cechami materiałów konwencjonalnych. Zbadano wpływ rodzaju wzmocnienia (włókno szklane, włókno węglowe i włókno Kevlar) na właściwości mechaniczne, termiczne i absorpcję wody laminatowych kompozytów polietylenu małej gęstości (LDPE) z żywicą epoksydową. Stwierdzono, że kompozyt LDPE z włóknem węglowym, w porównaniu z innymi kompozytami, wykazuje najlepszą wytrzymałość na rozciąganie, co może wynikać głównie z interakcji polimerowej osnowy z dwukierunkową warstwą włókien. Ponadto kompozyt ten ma większą zdolność przenoszenia energii niż pozostałe badane kompozyty, co można przypisać krystalicznej budowie włókna węglowego. Badania właściwości termicznych wykazały stabilność termiczną wszystkich kompozytów polimerowych wzmocnionych włóknami oraz znaczną absorpcję wody kompozytu wzmocnionego włóknem Kevlar.

Słowa kluczowe: kompozyty polietylenu małej gęstości, właściwości mechaniczne, badania termiczne, badania absorpcji wody, żywica epoksydowa, włókno Kevlar, włókno szklane, włókno węglowe.

1) Sathyabama Institute of Science and Technology, Department of Physics, Chennai-600 119, India.

2) Sathyabama Institute of Science and Technology, Department of Mechanical Engineering, Chennai-600 119, India.

3) King Saud University, College of Science, Department of Chemistry, P.O. Box 2455, Riyadh, Saudi Arabia 11451.

4) University of Malaya, Nanotechnology \& Catalysis Research Centre, Kuala Lumpur 50603, Malaysia.

*) Authors for correspondence: drsravichandran68@gmail.com; drsureshnano@gmail.com 
The increased interest of research in polymers and plastic reinforcement both from the academic, as well as industrial, point of view is due to the possibility to form hybrid composites with integrated structures allowing for the advancement of applications. In that direction, the commonly applied materials for the reinforcement of polymer matrices include metallic nanoparticles, asbestos, paper, wood, glass fiber, carbon fiber, aramid fiber (polyaramids), jute fiber, kenaf fiber, etc. [1, 2]. Among all, significant development has been made with the use of fiber reinforcement as the incorporation of these materials brought about concomitant changes in the volume fraction, architecture, and orientations to the final composite. Since the fibers are used as reinforcement to the polymers, it bears the load while the polymeric matrix functions to transfer the stress between the fibers, and thereby providing a barrier against the adverse environment that protects the fiber surface from mechanical abrasion $[2,3]$. Out of many different types of fibrous reinforcements for polymer matrices, the incorporation of glass fibers as the reinforcement has the special advantages of enriching the mechanical properties (like tensile strength), resistance to thermal and chemical degradations, electrically insulating properties and all can be possible at a relatively low cost. But the glass fiber-reinforced composite suffers from the limitations of very high density compared to the other fiber-reinforced composites like carbon and aramid. Carbon and aramid fibers, when used for the polymer reinforcement, have the advantages that include higher mechanical strength, lighter weight, higher dimensional stability, higher dielectric strength, resistance to corrosion, and flexibility to improve the material design. Similarly, the polymers used as adsorbents for the loading of the filler include epoxy, polyester/ vinyl ester thermosetting plastic, phenyl formaldehyde resin, etc. In one study, Banakar and Shivananda [4] investigated the mechanical properties of the carbon fiber reinforced epoxy resin composites like tensile and flexural strengths where the results indicated that the fiber orientation significantly influences the mechanical properties of the laminated polymer composites. They found that the $90^{\circ}$ orientation of fiber had superior properties of tensile and flexural strengths along with high load-bearing specimens, while the extension and deflection were maximum at $30^{\circ}$ and minimum at $90^{\circ}$ fiber orientation. A different study by Deogonda and Chalwa [5] showed that the mechanical properties of epoxy fiber composites were enhanced by glass fiber and with the addition of $\mathrm{ZnS}$ and $\mathrm{TiO}_{2}$ as the filler materials.

In general, the materials used for the aerospace, automobile, and marine industries possess many advanced characteristics and, in that view, low density polyethylene (LDPE) is a well-known commercial thermoplastic polymer that can offer many industrial applications like food and juice containers, waterproof surfaces, computer components, etc. The industrial applications of this LDPE material are due to its unique combination of properties like insulating behavior for electrical devices, mechanically strong nature and at the same time the capacity for the maintenance of thermal resistance [6]. When the LDPE material is used for the composite formation with other reinforcements and/or fillers, the generated hybrid composites possess the additional characteristics of high specific strength and modulus, excellent toughness against fractures, fatigue properties, good resistance to corrosion, etc. [6-8]. This unique combination of properties, in particular, the high strength to weight ratio, makes LDPE polymers and its composites a very attractive platform for transport applications. Therefore, to take advantage of the inbuilt properties of LDPE material, the present study deals with the LDPE composites containing epoxy resin, and various reinforcements such as glass, carbon, and Kevlar fibers. For the formation of the composites, we followed the compression molding method where the formed hybrid composites were characterized thoroughly and further studied towards the change in the mechanical, thermal, and water absorption properties.

\section{EXPERIMENTAL PART}

\section{Materials}

The polyethylene matrix used in this study was low density polyethylene (LDPE) copolymer resin grade produced by Sakthi fiberglass, Chennai, Tamilnadu, India. The density of the polymer was identified as $0.918 \mathrm{~g} / \mathrm{cm}^{3}$, melting point in the range of $114-133^{\circ} \mathrm{C}$. Similarly, the epoxy resin (LY-556), hardener (HY-917), glass fiber (WRM 610 GSM), carbon fiber, and Kevlar fiber used as the reinforcement materials were also obtained from the same Sakthi fiberglass company.

\section{Preparation of composite material}

For the fabrication of fiber-reinforced polymer (FRP) composites, we followed the compression molding method and, for that, a mixture of LDPE and toluene solvent was taken in the ratio of $1: 3$ and heated to a temperature of $190^{\circ} \mathrm{C}$ for $45 \mathrm{~min}$. After cooling to room temperature, the reaction mixture was washed with degassed ethanol, centrifuged, the precipitate separated out, and the product dried to see the formation of solidified, smooth LDPE in its powdered form. The obtained powder was transferred to a round bottom flask and subjected to mixing on a magnetic stirrer with that of epoxy resin and fiber by taking in a ratio of $1: 2: 3$ for LDPE powder, epoxy resin, and fiber, respectively. The mixture was allowed to stir for about $30 \mathrm{~min}$ or more until all the contents were blended well to form a homogeneous mixture and, after that, $10 \%$ of hardener was added to this mixture. A spacer of $5 \mathrm{~mm}$ thickness and $300 \mathrm{~mm} \times 300 \mathrm{~mm}$ (inner dimension) was mounted on the compression molding machine. Then layers of glass fibers were placed on one another by applying the LDPE and resin mixture. Both the sides 
of the spacer were covered by polyethylene sheet coated with wax. A constant temperature of $80^{\circ} \mathrm{C}$ and a pressure of $0.02 \mathrm{MPa}$ (3 psi) was maintained for $2 \mathrm{~h}$ for the FRP composite to be cured. The same procedure was adopted for the fabrication of LDPE-carbon and LDPE-Kevlar fiber composites too. The test specimen was prepared as per the ASTM standards (Fig. 1).

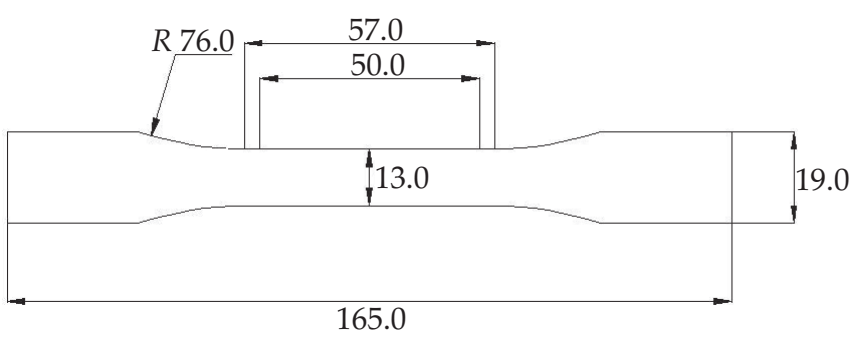

Fig. 1. Sample dimensions for the tensile strength tests

\section{Methods of testing}

\section{Hardness measurements}

The Charpy impact testing machine was used to determine the amount of energy absorbed in fracturing the test piece of composite material. The absorbed energy is a measure of the toughness of the material and serves as a tool for studying ductile-brittle transitions. Hardness measurements are used to find the resistance of a material to plastic deformation.

\section{Tensile test}

The hybrid polymer composite material was fabricated in the required dimension using a suitable cutter and the edges finished by using emery paper for the tensile testing. The tensile test specimen is prepared as per the ASTM D638 standard and the test involves the mounting of material in a machine and then subjecting it to various tensions until it fractures. The tensile force is recorded as a function of an increase in gauge length. During the application of different tensions, the elongation of the gauge section is recorded against the applied force.

\section{Flexural test}

The three-point flexural test is used to measure the flexural strength that is reasonably significant with a tensile test and for the test, the specimen is rested between two knife supports and the opposite probe produces a flexural effect repeatedly until it breaks. The flexural specimens are prepared as per the ASTM D790 standards where the three-point flexure test is the most common for testing the flexural properties of the composite materials. The specimen deflection is measured by the crosshead position and the test results include flexural strength and displacement. The testing process involves the placing of the test specimen in the universal testing machine and applying force to it until it forms fractures and breaks. The tests are carried out at $50 \%$ average relative humidity conditions.

\section{Test of water absorption}

Good matrix wetting of the fiber and adequate bonding of the fiber matrix can reduce the rate and quantity of water absorbed in the composite [9]. To determine the amount of water absorbed under the testing conditions, the water absorption tests of fiber-reinforced composites were done as per ASTM 570 by immersing the samples in distilled water at room temperature. The dried specimen's weight $\left(w_{1}\right)$ and after submerging the same material in distilled water for a $24 \mathrm{~h}$ period $\left(w_{2}\right)$ were recorded. The factors that affect water absorption characteristics like plastic-type, additives used, exposure temperature, and duration of soaking were also investigated. Due to the nature of the fibers, the water absorption of composites containing various reinforcement fibers (glass, carbon, and Kevlar) may be a limiting parameter for several composite applications. All the samples were dried completely before being immersed in water until we confirm the constant weight on a four-digit balance. The percentage of water consumption is calculated by Eq. (1) below.

$$
W A(\%)=\left[\left(w_{2}-w_{1}\right) / w_{1}\right] \cdot 100
$$

$w_{1}$ - initial weight of dried specimen (g) and $w_{2}-$ specimen weight after $N$ hours of water soaking $(g)$.

\section{RESULTS AND DISCUSSION}

\section{Mechanical properties}

To investigate the effects of type of reinforcement material on the LDPE's internal characteristics, the synthesized composites were first subjected to a wide range of mechanical tests. In general, the tensile properties of the composites were affected by the type of materials, preparation methods, specimen condition and preparation, and the percentage of reinforcement [10].

For the LDPE reinforced composites, the changes in the stress-strain behavior of fibers with respect to the rein-

$\mathrm{T}$ a b 1 e 1. Ultimate tensile strength, maximum force, breaking load, and energy absorption of fiber reinforced LDPE composites

\begin{tabular}{l|c|c|c|c}
\hline LDPE composites & $\begin{array}{c}\text { Ultimate } \\
\text { tensile } \\
\text { strength } \\
\mathrm{MPa}\end{array}$ & $\begin{array}{c}F_{\max } \\
\mathrm{kN}\end{array}$ & $\begin{array}{c}\text { Breaking } \\
\text { load } \\
\mathrm{kN}\end{array}$ & $\begin{array}{c}\text { Energy } \\
\text { absorbed } \\
\mathrm{J}\end{array}$ \\
\hline LDPE-epoxy resin & 120 & 7.2 & 0.05 & 0.01 \\
laminate & 298 & 20.6 & 1.3 & 8.6 \\
LDPE-glass fiber & 448 & 35.9 & 1.5 & 9.7 \\
LDPE-carbon fiber & 207 & 15.5 & 1.2 & 3.5 \\
LDPE-Kevlar fiber &
\end{tabular}


a)

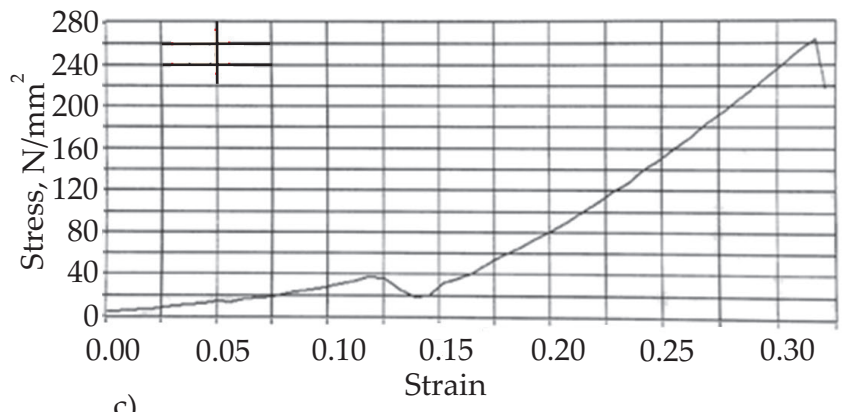

c)

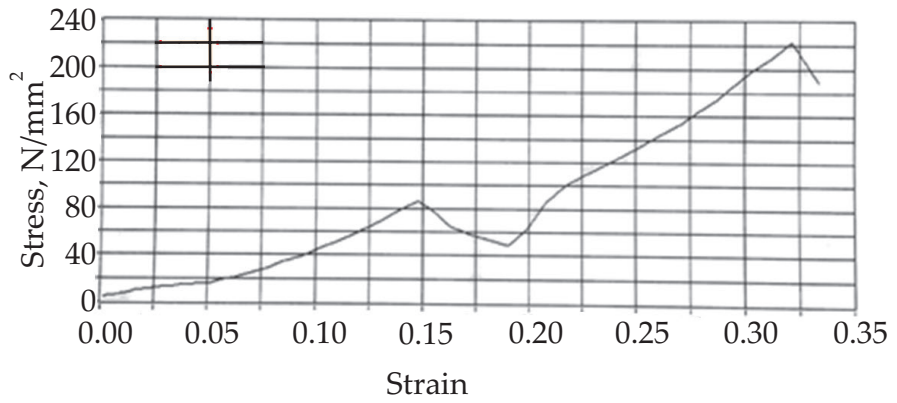

b)

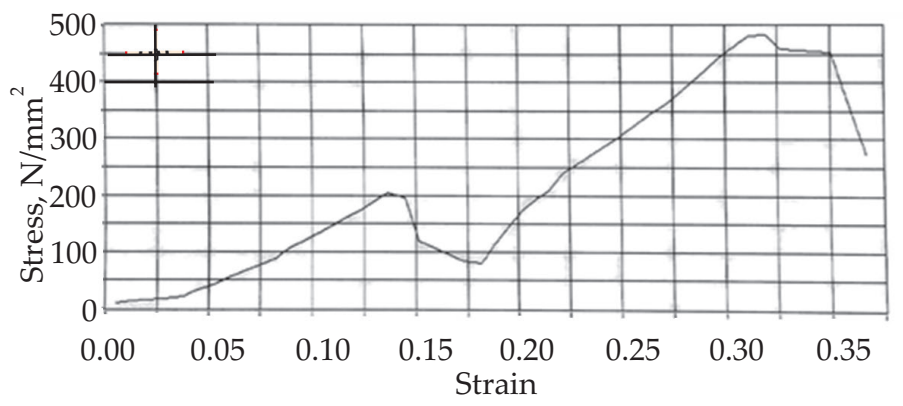

d)

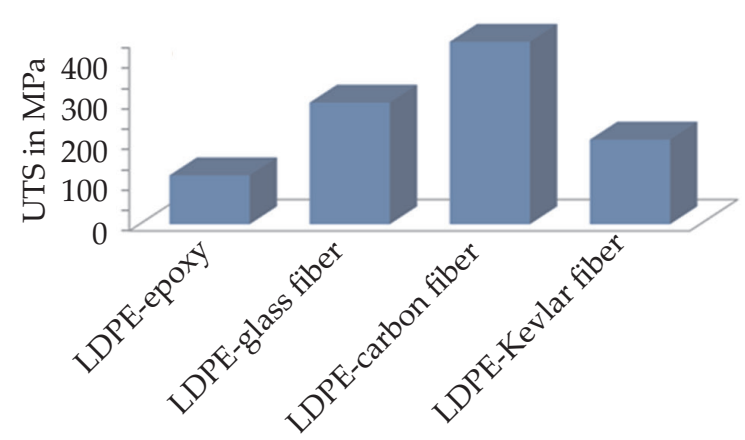

Fig. 2. Comparison of stress-strain graph for: a) LDPE-glass fiber, b) LDPE-carbon fiber, c) LDPE-Kevlar fiber, d) the variation of tensile strengths of the LDPE-resin with that of all other fiber reinforced composites

forcement material are shown in Fig. 2. Table 1 compares the tensile strength, breaking load (or breaking strength and the tensile strength at its break), energy absorption (maximum force applied), and impact energy of LDPE-epoxy resin with that of other fiber reinforcements like glass, carbon, and Kevlar fiber.

From Fig. 2, remarkable differences can be observed for the mechanical properties of LDPE with different reinforcing materials and we found that the carbon fiber reinforced LDPE composite has the superior properties of tensile strength and high impact energy compared to the other composites. From Table 1, it can be clearly noted that the carbon fiber reinforcement of LDPE led to a substantial improvement of stiffness to $448 \mathrm{MPa}$, followed by the glass fiber with $298 \mathrm{MPa}$, and Kevlar fiber with $207 \mathrm{MPa}$. The comparison of variation of tensile strengths of LDPE-resin with that of other fiber-reinforced composites shown in Fig. $2 \mathrm{~d}$ indicates that the value obtained for carbon fiber is 3.5 times higher than the pure LDPE-resin system. The observation of this high value of tensile strength and breaking loads for the carbon fiber reinforced LDPE composite satisfies the minimum requirement that any material needs to be maintained so as to employ in the manufacturing of sheet molded components. Further, these enhanced properties for the carbon fiber reinforced LDPE composite against the other composites of resin, glass, and Kevlar fibers can be attributed to the formation of a hybrid crystalline structure. Since the carbon fibers possess fully or halfway crystalline nature and, on composite formation with the LDPE, this allows the proper association of bonding between the polymer matrices and the bidirec- tional fiber layers [11]. Also, the carbon fibers that contain $\pi$ electrons become covalently bonded with other carbon atoms of LDPE as they both are in the same phase, while van der Waals forces support the increase of interactions between the layers. Similarly, the LDPE-glass fiber composite showed moderate improvement in its tensile strength compared to the LDPE-resin and this is attributed to the strength of silicon and other metals contained in the glass fibers. In addition, the strength of the LDPE-Kevlar fiber composite can be linked to the formation of an inter-chain bonds and associated strength acquired between the LDPE and fiber molecules by means of aromatic stacking interactions. These stacking interactions produce considerable influence on the Kevlar fiber than the van der Waals interactions and chain length, where the strength achieved is less for the stacking interactions compared to the van der Waals and for that reason, we observe less strength for the Kevlar fiber than the carbon

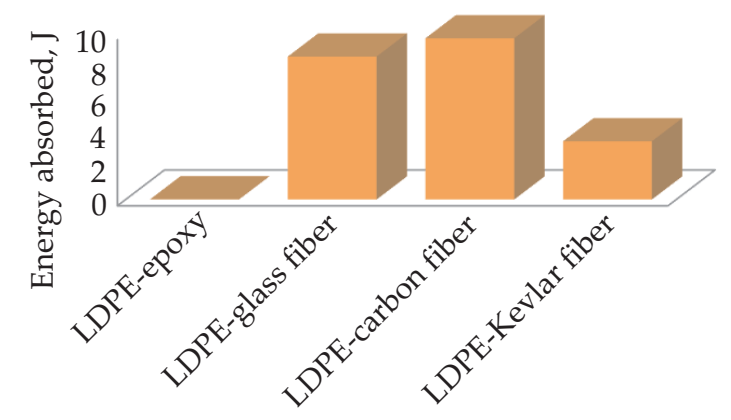

Fig. 3. Comparison of impact energy for the LDPE-resin when glass, carbon, and Kevlar fibers are used as reinforcements 
a)

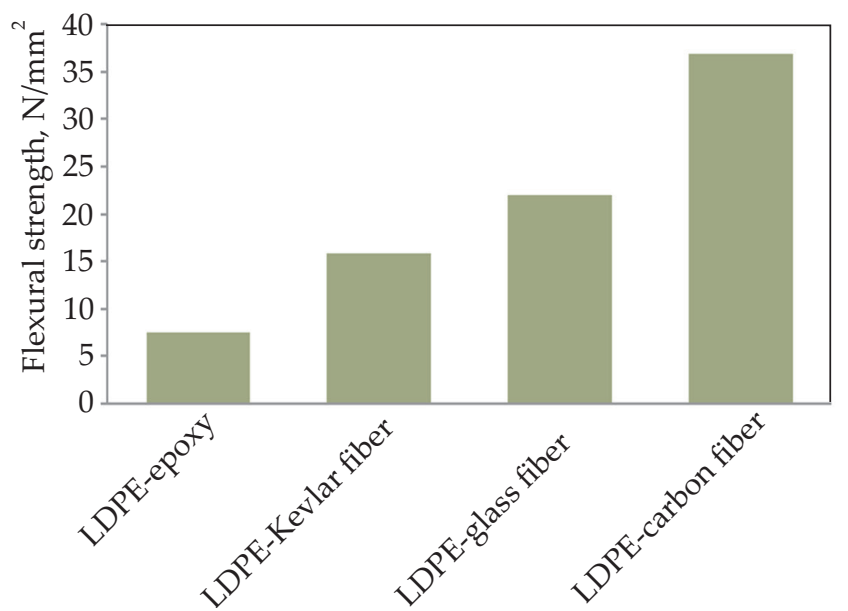

b)

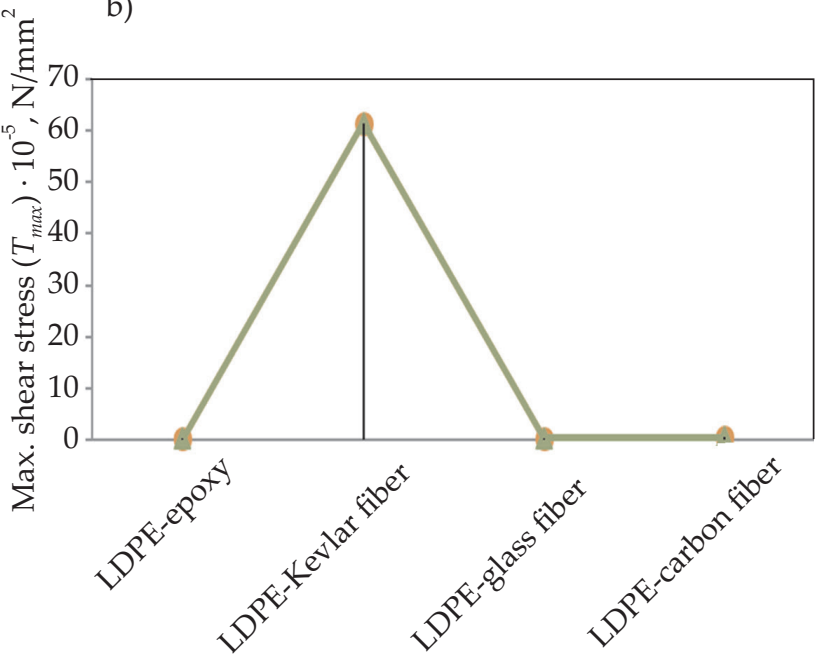

Fig. 4. Comparison of variations in the: a) flexural strengths, b) shear stress for the LDPE-fiber reinforced composites

fiber loaded LDPE composites [12, 13]. Overall, from the tensile study, it is concluded that the LDPE-carbon fiber-reinforced composite possesses the high tensile strength and breaking load compared with other fiber reinforcements.

A composite's impact strength is the ability of any material to resist fracture failures when the stress is applied suddenly at high speed and is interrelated with toughness. In a general term, it is the amount of energy required to break the specimen and as similar to the tensile strength these values also change with various parameters. Figure 3 and Table 1 (energy absorbed) show the impact values of LDPE composites formed with different fibers like glass, carbon, and Kevlar.

From Table 1, the LDPE composites reinforced with glass (8.6 J) and carbon (9.7 J) fiber have the highest impact energy as against the Kevlar fiber (3.5 J). Compared to the impact strength of plain LDPE-resin $(0.01 \mathrm{~J})$, the reinforcement of LDPE with the fibers has a significant enhancement in the energy absorption and this is due to the compression applied during the fiber reinforcement that eliminates the void space in the final composite [14, 15]. Also, within the three fiber reinforcement materials, the observation of higher impact value for the carbon fiber as against the glass and Kevlar may be expected due to the generation of the homogeneous composite structure for the former composite, which further helped for the effective dissipation of stress/load and prevented the polymer from cracking [16]. Hence, the LDPE-carbon fiber reinforcement with long fibers and effective bonding strength at the interfaces, supported by the same phase of carbon atoms, forms a homogeneous structure that helps to transfer the applied stress/energy uniformly.

Flexural strength is also linked to the mechanical properties of the composite where it is a measure of bending strength or fractural strength of the material. In general for the testing, the specimens are tested by subjecting a certain surface of the sample to the compression; however, failures can occur in tension at mid-span of the material.
The flexural strength for the three-point bend configuration for the prepared LDPE composites was calculated by Eq. (2)

$$
\sigma=3 F L / 2 b d^{2}
$$

where: $\sigma$ - the strength under axial force, $F$ - the maximum load applied, $L$ - the length of the supported span, $b$ - the specimen width, and $d$ - the thickness.

Similarly, the maximum shear stress $\left(\tau_{\max ^{\prime}}\right.$ force applied parallel to the surface to deform the material) at the neutral axis for the LDPE-fiber composites were calculated by Eq. (3)

$$
\tau_{\max }=3 F / 4 b d^{2}
$$

The results of flexural strength and shear stress for the LDPE-fiber composites are shown in Fig. 4 and the respective data for both is tabulated in Table 2 .

From the analysis of flexural strength data shown in Fig. 4a, all the composites exhibit values greater than the pure LDPE-epoxy laminated composite. As similar to the earlier tests of tensile and impact studies, the carbon fiber reinforced composites have a high flexural strength of $37 \mathrm{~N} / \mathrm{mm}^{2}$, followed by the glass fiber with $22 \mathrm{~N} / \mathrm{mm}^{2}$ and Kevlar fiber of $16 \mathrm{~N} / \mathrm{mm}^{2}$. The observation of such a higher flexural value for the carbon fiber composite supports the highly brittle nature compared to the other

T a b l e 2. Comparison of flexural strength, maximum shear stress, and hardness for the LDPE-fiber composites

\begin{tabular}{l|c|c|c}
\hline $\begin{array}{c}\text { Different LDPE } \\
\text { composites }\end{array}$ & $\begin{array}{c}\text { Flexural } \\
\text { strength } \\
\mathrm{N} / \mathrm{mm}^{2}\end{array}$ & $\begin{array}{c}\text { Max. } \\
\text { shear } \\
\text { stress } \\
\tau_{\max } \cdot 10^{-5} \\
\mathrm{~N} / \mathrm{mm}^{2}\end{array}$ & $\begin{array}{c}\text { Hardness } \\
\text { values } \\
\mathrm{N} / \mathrm{mm}^{2}\end{array}$ \\
\hline LDPE-epoxy resin & 7.5 & 0.1 & 80 \\
LDPE-glass fiber & 22 & 0.3 & 107 \\
LDPE-carbon fiber & 37 & 0.4 & 67 \\
LDPE-Kevlar fiber & 16 & 62 & 111 \\
\hline
\end{tabular}


fibers and pure LDPE. This may be related to the higher stiffness of carbon fibers and the ability of components within the LDPE-carbon fiber to redistribute across the fiber so as to withstand the load. As a result, the flexural strength of carbon fiber reinforced composite is 2.3 times greater than the Kevlar and 1.7 times greater than the glass fiber reinforcement. This remarkable improvement in the flexural strength of LDPE-carbon fiber composite against the other fibers may be attributed to the C-C coupling effect of fiber with that of the LDPE polymer thereby making the composite more homogeneous. Turla et al. [17] investigated the flexural strength of carbon and glass fiber reinforced epoxy based hybrid composites where the results indicated higher values for carbon composites against glass ones. Based on the literature studies and from our data, it can be concluded that the flexural strength is dependent on the fiber material type and a significant enhancement in those properties can be achieved by reinforcing the polymers with that of fibers $[18,19]$. In a similar way, the comparison of shear stress values [obtained using Eq. (3)] for the LDPE composites shown in Fig. $4 \mathrm{~b}$ and Table 2, it was observed that the LDPE-Kevlar fiber composite has the highest value of $62 \cdot 10^{5}\left(\mathrm{~N} / \mathrm{mm}^{2}\right)$, while all other composites exhibited negligible values of $<0.5 \cdot 10^{5}\left(\mathrm{~N} / \mathrm{mm}^{2}\right)$. The higher value of shear stress (tangential stress) indicates that

a)

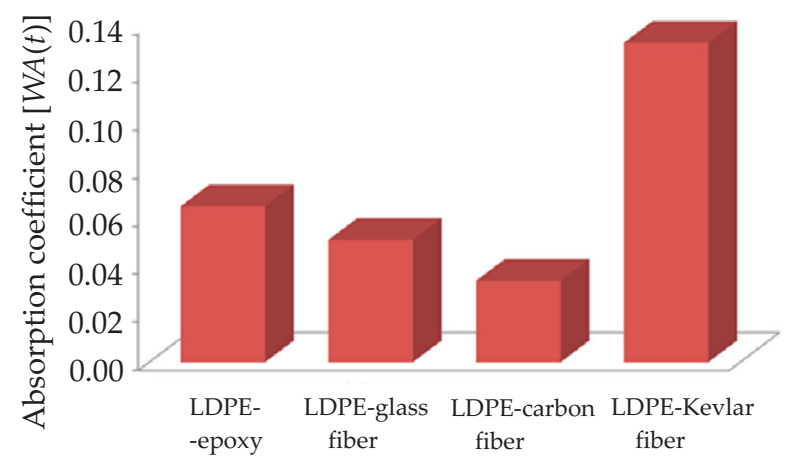

the LDPE-Kevlar composite maintains greater slippage capacity all along the planes in parallel to the applied force, while no such capacity is seen for the other fiber-reinforced composites.

Hardness is also one of the main characteristics of a polymer material where it determines the degree of the material's deformation and is generally accepted as a significant property. This is defined as the indentation resistance and determined by measuring the indentation's permanent depth. In Wilson hardness testing of LDPE-fiber composites, a load was applied from $10-60 \mathrm{~kg}$ to the specimen for a Dwell time (time spent in the same position) of $5 \mathrm{~s}$ and the hardness values were measured. The results obtained from the Wilson hardness test with our LDPE-resin polymer composites of different fiber reinforcements are also tabulated in Table 2. From the comparison of values, it indicates that the hardness of the composites is varied with respect to the nature of fiber reinforcement. The composites with glass and Kevlar fiber have high hardness values because of the alignment and the length of the fibers, which lead to the contribution of the loads along the fibers. However, the LDPE-carbon fiber composite maintains a lower value of hardness and because of a homogeneous mixture that allowed for the improved interaction among the groups of LDPE matrix and the carbon fiber [20, 21]. b)

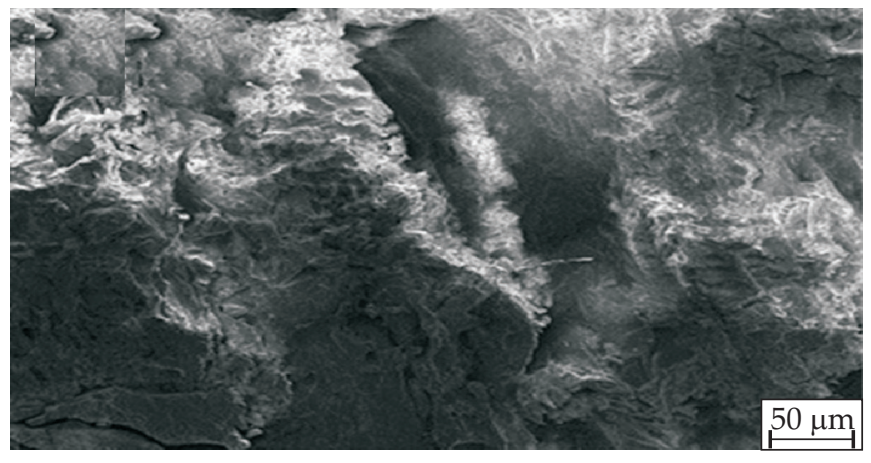

c)

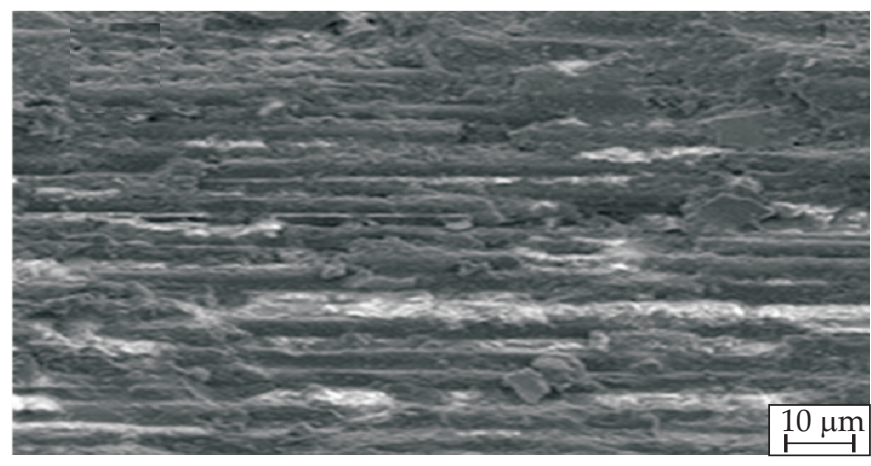

Fig. 5. Comparison of the: a) water absorption coefficient of various LDPE-fiber composites, b) SEM fractional section of LDPE-epoxy resin composite, c) LDPE-carbon fiber-reinforced composite 


\section{Water absorption studies}

Water absorption may adversely affect several mechanical properties and can also increase the moisture content in fiber walls and interphase regions of the fiber matrices and so the test of water absorption is a very important one for determining the outdoor work potential of fiber-reinforced composites. These performances of the composites may suffer if they are exposed to various environmental conditions and the physical properties of the fiber material like the changes in surrounding temperature, fiber size and volume fraction, fiber type and orientation, total exposed area, diffusivity, interface bonding, void space, viscosity and surface protection, water-matrix interaction, etc. In general, a good matrix wetting of the fiber and adequate bonding of fiber with that of a polymer matrix can reduce the amount and rate of water absorbed in the interphone region of the composite $[22,23]$. Therefore, to investigate the extent of interaction between the epoxy resin, fiber, and LDPE groups, the LDPE-epoxy resin and LDPE-fiber reinforced composites were tested for water absorption and the results are provided in Fig. 5a. From the data showed in Fig. 5a, it is indicated that the composite with Kevlar fiber has high water absorption, while the composite with carbon fiber

a)

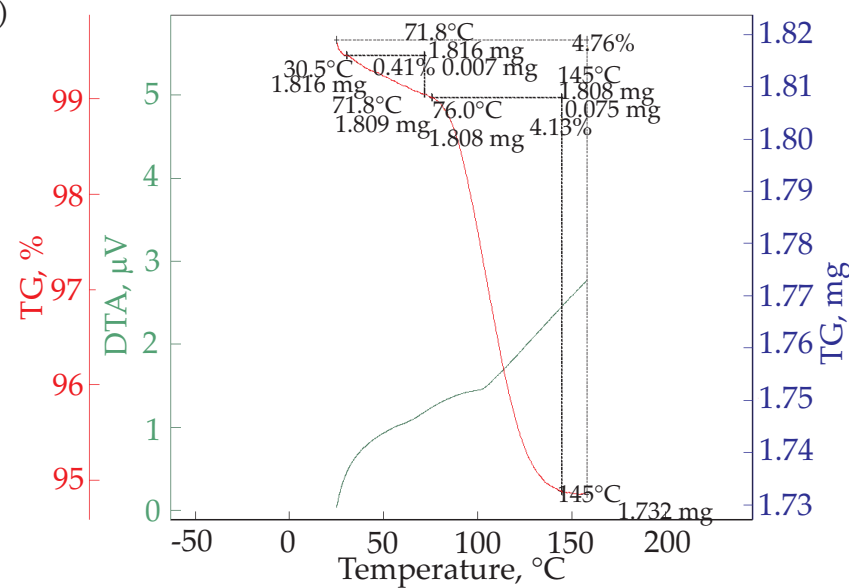

c)

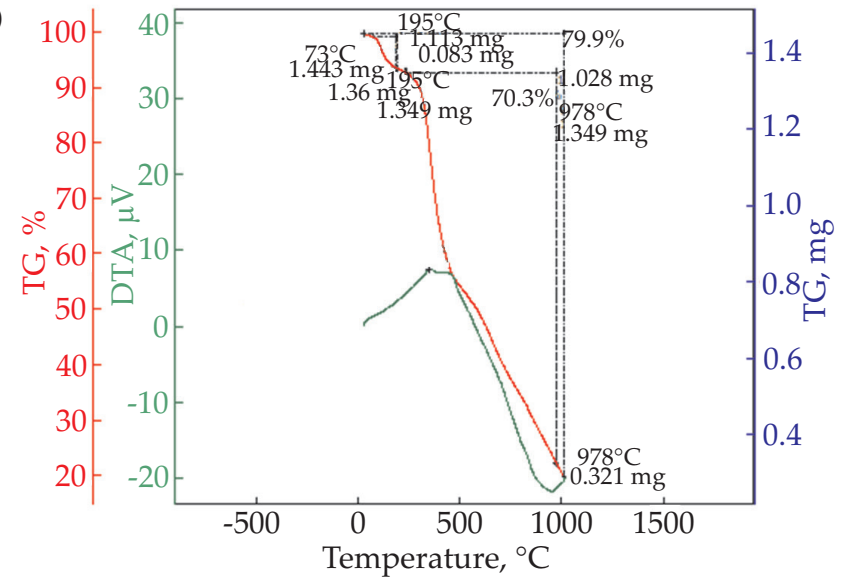

has a lower water absorption coefficient and this value is even less than the LDPE-epoxy resin. The observation of lower water absorption for the LDPE-carbon fiberreinforced composite may be attributed to the absence of voids and cavities in the composite. However, for the Kevlar fiber composite, there may be much space at the interface region between the fiber and matrix which supported a higher water intake.

To confirm the water absorption phenomenon, SEM studies were performed using the LDPE-epoxy resin and the LDPE-carbon fiber-reinforced composite where the results are shown in Figs. 5b, 5c. The SEM image of the epoxy resin sample (Fig. 5b) indicated a heterogeneous sponge like morphology, and one can clearly identify the LDPE and epoxy resin in two different phases. However, for the SEM of the carbon fiber composite (Fig. 5c), the homogeneity of the polymer matrix along with the fiber reinforcements is maintained, in addition to the lack of spongy nature. Further, the physical observations of LDPE-epoxy resin powder indicated for the soft and spongy nature, while the LDPE-carbon fiber sample for rigid and stiff behavior. From the morphological analysis, it can be confirmed that the reinforcement of the LDPE matrix with that of carbon fiber brings some changes to the physical structure and that the formed homogeneous
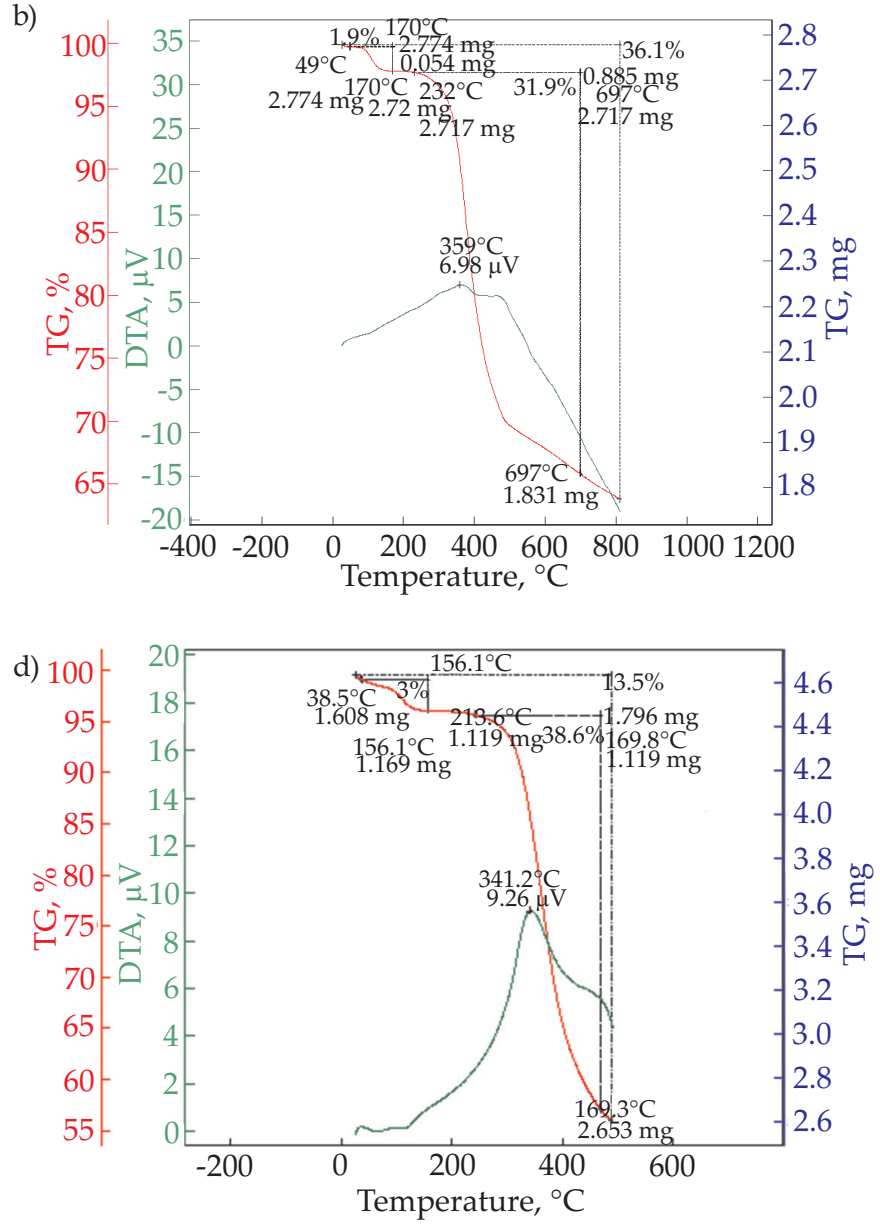

Fig. 6. TG and DTA analysis of: a) LDPE with resin composite, b) LDPE-glass fiber, c) LDPE-carbon fiber, d) LDPE-Kevlar fiber reinforced composites 
composite allows for the absorption of only limited water content.

\section{Thermal analysis}

TGA and DTG are used to characterize the decomposition and thermal stability under various conditions and to analyze the degradation kinetics of the physicochemical processes of the samples. Figure 6 shows the TGA and DTG analysis for the LDPE-epoxy and LDPE-fiber reinforced composites where, for the testing, the initial sample weights were taken in the range of $2-5 \mathrm{mg}$ and were heated at a heating rate of $20^{\circ} \mathrm{C} / \mathrm{min}$ from room temperature to higher levels. The weight loss usually indicates the rate of decomposition of polymers and often provides mechanisms for degradation and other important information related to physicochemical changes in different environments [24]. From Fig. 6a, the TGA of LDPE-epoxy resin represents a dynamic weight loss profile and for the LDPE-fiber composites, the major degradation occurrs in two steps, one due to fiber degradation while the other from polymer degradation. We observed the initial decomposition of material in the temperature range of $200-300^{\circ} \mathrm{C}$, where the weight losses appeared to be very less and may be due to the loss of adsorbed water/moisture. The second weight loss stage occurred in the range of $400-750^{\circ} \mathrm{C}$ and can be linked to the degradation of the polymer present in the composites. From the TGA curves of the LDPE composites, we observed significant weight losses in the range of $170-800^{\circ} \mathrm{C}$ with the glass-reinforced fiber (Fig. 6b), $195-978^{\circ} \mathrm{C}$ for the carbon fiber (Fig. $6 \mathrm{c}$ ), and $156-470^{\circ} \mathrm{C}$ for the Kevlar fiber (Fig. 6d). The complete decomposition of the composite material was observed around $1000^{\circ} \mathrm{C}$ in LDPE with carbon fiber, at $800^{\circ} \mathrm{C}$ for the glass fiber, and $470^{\circ} \mathrm{C}$ for the Kevlar fiber-reinforced composites. Overall, we observed a $65.8 \%$ residue at $697^{\circ} \mathrm{C}$ with the glass fiber, $22 \%$ at $978^{\circ} \mathrm{C}$ for the carbon fiber, and $57 \%$ residue at $469^{\circ} \mathrm{C}$ for the Kevlar fiber-reinforced composites. This indicates that the LDPE-carbon fiber composite has significant thermal stability as it can be able to withstand a heating temperature of $978^{\circ} \mathrm{C}$ with $22 \%$ residual weight.

In a similar way, with the DTA analysis of LDPE-fiber reinforced composites, we observed polymer degradations around $359^{\circ} \mathrm{C}$ for the glass fiber (Fig. $6 \mathrm{~b}$ ), $350^{\circ} \mathrm{C}$ for the carbon fiber (Fig. $6 \mathrm{c}$ ), and $341^{\circ} \mathrm{C}$ for the Kevlar fiber (Fig. 6d) reinforced composites. Since the LDPE is a crystalline polymer and it is common to observe such degradation peaks linked to phase changes, the obtained results can be compared, and are consistent, with literature studies $[25,26]$. The curve also shows that thermal degradation only started to occur after absorbing certain amounts of heat energy by the composite materials. Under the heat absorbed conditions, the degradation processes are initiated and this helps the breakdown of the fiber structure and polymer matrix by causing ruptures in the molecular chain. Rezaei et al. [27] and Zabihzadeh et al. [28] reported similar results of thermal degradation of fibers and polymer matrices occurring due to molecular chain ruptures. Thus, from the comparison of peaks found in the TGA and DTG curves, the physical structure of the LDPE polymer matrix seems to change after fiber reinforcement and this significantly affected the thermal degradation process of the composites.

\section{CONCLUSIONS}

We studied the thermal, mechanical, and water absorption characteristics of LDPE matrices with epoxy resin and other composites reinforced with glass, carbon, and Kevlar fibers. From the studies of mechanical properties, we observed a significant improvement in the fiberreinforced composites compared to the LDPE with epoxy resin. Within the fiber-reinforced composites, the LDPE-carbon fiber has high tensile strength and impact energy, while the LDPE-Kevlar composite has the highest hardness only. On testing the behavior of composites towards water absorption, we found that the LDPE-Kevlar fiber is very sensitive to swelling as it showed the maximum absorption coefficient and can be linked to the nature of the fiber and voids in the polymer matrix and least for the LDPE-carbon fiber. Further, the thermal studies confirmed that with the reinforcement of carbon fiber, the thermal stability of LDPE composite increased significantly. Overall, as compared to the non-reinforced polymer matrices, the reinforcement of the LDPE matrix with fiber has significant properties of mechanical, thermal, and water absorption and within the different fibers, the carbon fiber reinforcement is the most influential one due to the modifications occurring in its morphology. Further, these composites can be incorporated directly for various industrial applications by taking advantage of the limited/no water absorption property of LDPE-carbon fiber composite and high water absorption of LDPE-Kevlar fiber, in addition to the thermal and mechanical stability of LDPE-carbon fiber. Finally, the enhancement in the mechanical and other physical properties due to the fiber reinforcement due to morphological changes can be explored to form composites with other polymer matrices that have a significant effect on the industrial product development.

\section{ACKNOWLEDGMENTS}

This work was financially supported by the University of Malaya Research Grant (RU001-2018, RU001-2019). The authors also acknowledge funding of this work by the Research Supporting Project (RSP-2019/54), King Saud University, Riyadh, Saudi Arabia.

\section{REFERENCES}

[1] Rajak D.K., Pagar D.D., Kumar R., Pruncu C.I.: Journal of Materials Research and Technology 2019, 8, 6354. https://doi.org/10.1016/j.jmrt.2019.09.068 
[2] Adeniyi A.G., Onifade D.V., Ighalo J.O., Adeoye A.S.: Composites B Engineering 2019, 176, 107305. https://doi.org/10.1016/j.compositesb.2019.107305

[3] Gnaba I., Legrand X., Wang P., Soulat D.: Journal of Industrial Textiles 2019, 49, 71. https://doi.org/10.1177/1528083718772299

[4] Prashanth Banakar, Shivananda H.K.: Journal of Mechanical Civil Engineering 2012, 1 (2), 15. http://dx.doi.org/10.9790/1684-0131518

[5] Deogonda P., Vijaykumar Chalwa N.: International Journal of Scientific Engineering and Research 2013, 1 (4), 6.

[6] Jordan J.L., Casem D.T., Bradley J.M. et al.: Journal of Dynamic Behavior of Materials 2016, 2, 411. http://dx.doi.org/10.1007/s40870-016-0076-0

[7] Khanam P.N., AlMaadeed M.A.A.: Advanced Manufacturing: Polymer and Composites Science 2015, $1,63$. https://doi.org/10.1179/2055035915Y.0000000002

[8] Dintcheva N.Tz., Filippone G., Arrigo R., La Mantia F.P.: Journal of Nanomaterials 2017, ID 3549475. https://doi.org/10.1155/2017/3549475

[9] Wang Q., Liu C., Chen Y.: Plastics, Rubber and Composites Macromolecular Engineering 2001, 30, 363. https://doi.org/10.1179/146580101101541741

[10] Nassar A., Nassa E.: Nanoscience and Nanoengineering 2013, 2, 89. http://dx.doi.org/10.13189/nn.2013.010201

[11] American Standard of Testing Material (ASTM): "Standard test method for tensile properties of reinforced thermosetting plastics using straight-sided specimens", ASTM Int West Conshohocken, Pa, USA, pp. 32-37, 2004.

[12] Rahmani H., Mahmoudi Najafi H.S., Ashori A.: Journal of Reinforced Plastics and Composites 2014, 33, 733. http://dx.doi.org/10.1177/0731684413518255

[13] Atuanya C.U., Edokpia R.O., Aigbodion V.S.: Results in Physics 2014, 4, 88. http://dx.doi.org/10.1016/j.rinp.2014.05.003

[14] Banakar P., Shivananda H.K., Niranjan H.B.: International Journal of Pure and Applied Sciences and Technology 2012, 9, 61.
[15] Etcheverry M., Barbosa E.S.: Materials 2012, 5, 1084. https://doi.org/10.3390/ma5061084

[16] Arbelaiz A., Fernandez B., Ramos J.A., Retegi A.: Composites Science and Technology 2005, 65, 1582. http://dx.doi.org/10.1016/j.compscitech.2005.01.008

[17] Turla P., Kumar S.S., Reddy H.P., Shekar K.Ch.: International Journal of Engineering Research and Technology 2014, 3, 394.

[18] Amuthakkannan P., Manikandan V., Winowlin Jappes J.T., Uthayakumar M.: Materials Physics and Mechanics 2013, 16, 107.

[19] Jang J., Han S.: Composites Part A 1999, 30, 1045.

[20] Joseph P.V., Joseph K., Thomas S.: Composites Science and Technology 1999, 59, 1625. https://doi.org/10.1016/S0266-3538(99)00024-X

[21] Al- Hasani Emad S.: Engineering and Technology 2007, 25, 988.

[22] Nitz H., Reichert P., Romling H.,Mülhaupt R.: Macromolecular Materials and Engineering 2000, 276$277,51$.

h t t p s : / / d o i.org / 10.1002 / ( S I C I ) 1439 2054(20000301)276:1<51::AID-MAME51>3.0.CO;2-Z

[23] Huner U.: Advances in Science and Technology Research Journal 2015, 9, 1. https://doi.org/10.12913/22998624/2357

[24] Prabhu T.N., Demappa T., Harish V.: Journal of Applied Chemistry 2012, 2, 39.

[25] Chung D.D.L.: Thermochimica Acta 2000, 364, 121. https://doi.org/10.1016/S0040-6031(00)00631-6

[26] Liufu S.C., Xiao H.N., Li Y.P.: Polymer Degradation and Stability 2005, 87, 103. https://doi.org/10.1016/j.polymdegradstab.2004.07.011

[27] Rezaei F., Yunus R., Ibrahim R.A.: Materials and Design 2009, 30, 260. https://doi.org/10.1016/j.matdes.2008.05.005

[28] Zabihzadeh S.M., Dastoorian F., Ebrahimi G.: Journal of Reinforced Plastics and Composites 2010, 12, 1814. https://doi.org/10.1177/0731684409335455

Received 3 IX 2019. 